\title{
Strategies of Metacognition Based on Behavioural Learning to Improve Metacognition Awareness and Mathematics Ability of Students
}

Mohamad Salam

Dr., D.M.E., Halu Oleo University, Indonesia, mohamad.salam@uho.ac.id

\section{La Misu}

Dr., D.M.E., Halu Oleo University, Indonesia, lamisu_fkip@uho.ac.id

Utu Rahim

D.M.E., Halu Oleo University, Indonesia, uturahim56@gmail.com

Nanik Hindaryatiningsih

Dr., Universitas Halu Oleo, Kendari, Indonesia,nani_unhalu@yahoo.co.id

\section{Abd Rahman A. Ghani}

Prof., Universitas Muhamadiyah Prof. Dr. Hamka Jakarta, Indonesia, rahman.ghani@uhamka.ac.id

This study aims to develop student metacognition strategies based on behavioural learning in improving the mathematical abilities of students of mathematics education. There are two components developed in this study, namely: (1) Development of strategies to foster student metacognition based on behavioural learning, and (2) Development of learning tools consisting of: (a) test and search interview guidance levels or levels of student metacognition, and ( b) test students' mathematical abilities. The stages of developing this learning model refer to the four stages of developing a model known as the 4-D model, namely define, design, develop, and disseminate. Based on the process of developing the model, the following behavioural-based metacognition models/strategies were established. (1) Selection of learning approaches using a cooperative approach of Think Pair Share (TPS) type. (2) Studying lecture material by discussing with their partners. (3) Presenting lecture material by group members appointed in turn in front of the class. (4) Member response another group of material offerings from the presenter group. and (5) Giving a summary or affirmation of the material as well as positive reinforcement and negative reinforcement.

Keywords: metacognition, behavioural learning, metacognition awareness, mathematical ability, mathematics education

Citation: Salam, M., Misu, L., Rahim, U., Hindaryatiningsih, N., \& Ghani, A. R. A. (2020). Strategies of Metacognition Based on Behavioural Learning to Improve Metacognition Awareness and Mathematics Ability of Students. International Journal of Instruction, 13(2), 61-72. https://doi.org/10.29333/iji.2020.1325a 


\section{INTRODUCTION}

In the beginning, learning practices in the Mathematics Education Department tended to be done conventionally through oral communication techniques. Such conventional learning practices tend to emphasize how lecturers teach (teacher-centered) rather than how students learn (student-centered), and overall the results do not contribute much to improving the quality of student learning processes and outcomes.

Starting in the 2012/2013 academic year, learning practices in learning elementary mathematics (Number Theory) were changed by the group approach. Students are grouped into groups and given an assignment by the lecturer to summarize one of the basic mathematical material topics specified in the paper, and present it to the class. Other groups respond and provide input or ask questions about the material presented by the presenter group. The implementation of this assessment runs until the 2013/2014 academic year. However, this model does not all active group members participate. The activeness in a group is dominated by high-ability students, while students with weak abilities have never been involved in the preparation of papers or when presenting papers in front of the class. If viewed from student learning outcomes through this approach as follows: 2012/2013 academic year ranged from $47.05 \%$ (out of 34 students) obtained a score of 60 and above, and the academic year 2013/2014 ranged from $35.13 \%$ (out of 37 students) obtained grades 60 and above (La Misu, 2014).

In the 2014/2015 academic year, the approach to the elementary mathematics learning process was developed again with an approach that seeks each student to participate actively, namely applying behavioural theory by modifying the NHT type cooperative learning model. This approach is named the Behavioural Learning Model. In general the application of this model, students are grouped into seven groups and each group consists of 8 people, and each of them is given a different number from number 1 to number 8. Each group is given a task by the lecturer to summarize one of the topics of the Number Theory specified in a paper. Each group member is entrusted with presenting a specific topic, and the other group members with the same number are given the task of responding to the offerings from the group of presenters. Thus, the behaviour theory above will provide character education to students so they can prepare material in a paper to be presented in front of the class, can respond to other people's opinions, and there will be discussions between students both in groups and between groups. So that overall the student can actively take part in the lecture. The strength of this behavioural learning theory is to provide satisfactory treatment to students so that it can influence their thoughts and behaviour. This is consistent with Edward Thorndike suggesting that: "set the law of effect which means that any behavior that is followed by pleasant consequences is likely to be repeated, and any behavior followed by unpleasant consequences is likely to be avoided" (Gray, 2011). Then, B.F. Skinner is known by the theory of Law of operant conditioning that if the emergence of behaviour is accompanied by a stimulus, then the strength of the behaviour will increase (Slavin, 2011). According to Thorndike learning is the formation of associations between events called stimulus and response. That is, the existence of activities and there are various responses to various situations is elimination of various responses that are wrong, as 
well as the progress of reactions to achieve the goal. While the core of Skinner's behaviorism theory is operant conditioning, a form of learning in which the consequences of behavior produce changes in the probability of the behavior will be repeated.

The results of applying the behavioral learning model above, if seen from the results of student learning that around $51.78 \%$ (out of 56 students) scored 60 and above. Likewise, in the learning process that all students actively participate, both during the preparation of material in the paper, presentation of topics in front of the class, as well as responses from other groups. While the mastery of the concept of this material as a whole has not been satisfactory (La Misu, 2014). Based on the observations from the learning process, it can be seen that there are still many students in presenting mathematical material that does yet understand the concept of the material and only memorizes the material that is already available in the book or teaching material. Likewise, there are still many people who have not yet understood the solution to the sample or theorem. Thus, the application of this behavioural learning model that appears to be only a process of student participation and activity in following the learning process. However, there is still many problems in understanding the material content and how to present the material in the class. Therefore, with this behavioural learning model the writer wants to see student metacognition when presenting material and solving problems or proving theorems in front of the class.

The concept of metacognition as stated by Koriat (2007) that metacognition refers to what people know about cognition in general and specifically about their cognitive processes, and how they use metacognition knowledge to adjust their information processes and behavior (Goh, 2008). Then Flavell (1979) suggested that the concept of metacognition to determine the awareness of thought processes: what we think, how we think when facing certain tasks or situations, and why we think in certain ways. Metacognition includes the ability to monitor this process. Furthermore, Wells (2009) revealed that metacognition is a thought that is applied to the mind. That is, metacognition of thinking about thinking (Iwai, 2011). Biryukov (2003) and Hecker (1998) suggest that the concept of metacognition is an assumption of a person's thoughts about his thoughts which include metacognitive knowledge (one's awareness of what he knows), metacognitive skills (one's awareness of something he does) and metacognitive experiences (one's awareness of cognitive abilities it has).

Metacognitive has a role in regulating and controlling one's cognitive processes in learning and thinking more effectively and efficiently. Furthermore, Tacccasu (2008) defines metacognition, which is part of planning, monitoring, and evaluating the learning process and awareness and control of the learning process. To improve metacognitive skills, there is a need for awareness that students must have in their thinking processes. However, each student has different abilities in responding to a problem. Some students consciously pay attention to the problem given by completing it hierarchically, but there are also students who carelessly answer when faced with the task/problem. This is caused by students' different levels of metacognitive awareness. The level of one's awareness in the thought process according to Swartz and Perkins 
(1989), and adapted by several experts including: Fisher (1998), Fogarty (1994), Jansen \& de Klein, (2005), and Kraler (1995) include, (a) Level 1: tacit use, is a type of thinking in making decisions without thinking about the decision. Students only try or as long as they answer in solving problems, (b) Level 2: aware use is a type of thinking that shows someone is aware of "what" and "when" he does something. Students realize everything that is done in solving problems, (c) Level 3: strategic use is a type of thinking that shows organizing his thoughts by being aware of specific strategies that improve thinking accuracy. Students can use and be aware of the right strategies in solving problems, and (d) Level 4: reflective use is a thinking that shows someone reflecting on their thoughts by considering acquisition and how to improve it. Students are aware and able to correct mistakes made in solving problems. In line with this Fogarty explained that metacognition regulates cognitive processes. High-ability students have a level of reflective metacognition as well as strategic use. Students who are capable of having a level of strategic metacognition may also be aware of use. While low-ability students have a level of metacognition that may also be tacit use (David. 2010).

Based on the description above, the author will develop a learning strategy that involves student metacognition based on behavioural learning to improve mathematical skills in mathematics education students. This learning strategy will train and reveal students' metacognitive awareness in understanding mathematical concepts when learning takes place. So that students are aware of how to understand mathematical concepts, how to solve problems based on mathematical concepts, and be aware of how to convey/express mathematical concepts to others.

Thus, the problems of this study are (1) how the form of metacognition strategies based on behavioural learning in Mathematics Education students? and (2) whether the application of behavioural-based metacognition strategies can improve metacognition awareness and mathematical abilities of mathematics education students? This research was conducted in 3 stages, namely: (1) Creating a behavioural based metacognition strategy. (2) Implementing behavioural-based metacognition strategies for mathematics education students, and (3) seeing the results of Metacognition awareness and mathematical abilities of mathematics education students.

\section{METHOD}

This research is a type of research and development or Research and Development ( $R$ \& D). Research and development are research methods used to produce certain products and test the effectiveness of these products. The stages of developing this learning model refer to the four stages of model development proposed by Thiagarajan, Semmel and Semmel (1974) known as the 4-D model, namely define, design, develop, and disseminate. The subjects of this study were students of the Mathematics Education Program at the University of Halu Oleo Academic Year 2018/2019, the first semester who programmed the Differential Calculus course, consisting of class A there were 44 students and class B had 40 students. The effectiveness of the data and the effectiveness of the learning model and device were analyzed descriptively. The implementation criteria used refer to the methods of grading in summative evaluation from Bloom, 
Madaus\& Hastings (1981). Criteria for model quality/learning strategy developed, referring to Nieveen's criteria (1999), namely validity, practice, and effectiveness.

\section{FINDINGS AND DISCUSSION}

\section{Metacognition Strategy Based on Behavioural Learning}

Based on the understanding of metacognition and behavioural learning and supporting theories in the learning process, a form of metacognition strategy was developed to increase metacognition awareness and mathematical abilities of mathematics education students as shown in Table 1.

Table 1

Forms of Behaviour-Based Metacognition Strategies

\begin{tabular}{|c|c|}
\hline Stage / Phase & ctivities \\
\hline $\begin{array}{l}\text { Phase } 1 \text {, } \\
\text { Cooperative selection as a } \\
\text { learning approach }\end{array}$ & $\begin{array}{l}\text { a. The learning approach uses a cooperative model with } \\
\text { Think Pair Share (TPS) type } \\
\text { b. The lecturer divides each group of } 2 \text { members. } \\
\text { c. The lecturer distributes lecture material about the concept } \\
\text { of differential calculus to all group members. }\end{array}$ \\
\hline $\begin{array}{l}\text { Phase } 2 \text {, } \\
\text { Group members study and } \\
\text { discuss lecture material } \\
\text { provided by the lecturer }\end{array}$ & $\begin{array}{l}\text { a. Each group member studies the lecture material that has } \\
\text { been set by the lecturer. } \\
\text { b. All group members discuss with their partners to equate } \\
\text { understanding / perception of lecture material. } \\
\text { c. The lecture material that will be presented by group } \\
\text { members is the result of shared thoughts by group } \\
\text { members. }\end{array}$ \\
\hline $\begin{array}{l}\text { Phase } 3 \text {, } \\
\text { Presentation of lecture } \\
\text { material by groups } \\
\text { appointed in front of the } \\
\text { class }\end{array}$ & $\begin{array}{l}\text { The designated group members present lecture material on } \\
\text { topics that have been assigned in turns in front of the class. }\end{array}$ \\
\hline $\begin{array}{l}\text { Phase } 4 \text {, } \\
\text { The response of other } \\
\text { group members to the } \\
\text { material presentation from } \\
\text { the designated group }\end{array}$ & $\begin{array}{l}\text { a. The responses of other group members are addressed to } \\
\text { the same number of presenters. } \\
\text { b. The responses of other group members are addressed to } \\
\text { different numbers of presenters. } \\
\text { c. The feedback from the group presenters is according to } \\
\text { the concepts they present and can be helped by their } \\
\text { group friends. }\end{array}$ \\
\hline $\begin{array}{l}\text { Phase } 5 \text {, } \\
\text { Giving a summary or } \\
\text { affirmation of material as } \\
\text { well as positive } \\
\text { reinforcement and negative } \\
\text { reinforcement }\end{array}$ & $\begin{array}{l}\text { a. The lecturer gives a summary and affirmation of the } \\
\text { material while straightening out the wrong material } \\
\text { presentation } \\
\text { b. The lecturer gives positive reinforcement to the presenter } \\
\text { if the dish is satisfying and the reinforcement is negative } \\
\text { if the dish is unsatisfactory. Likewise for other group } \\
\text { members who respond. }\end{array}$ \\
\hline
\end{tabular}

Table 1 above, reveals the form of behavioural learning based metacognition strategy that describes the metacognition awareness of students in studying lecture material. The 
detailed description of each phase of the behavior-based metacognition strategy is as follows: (1) The selection of learning approaches using the TPS type cooperative approach, aimed at making group members more familiar and not reluctant to group members in discussions. (2) Study lecture material by discussing with their partners, aiming for each group member to listen to each other or voice ideas/results of his thoughts (metacognitive knowledge) and equate perceptions of the study material he learned. (3) Presenting lecture material by group members appointed in turn in front of the class, the goal is that all group members be brave and able to voice their ideas/results of thoughts (metacognitive knowledge) about the lecture material they study in front of the class. (4) The responses of other group members to the material presentation from the presenter group, aiming for the members of the presenter group to be aware of the knowledge they already have whether it is right or still wrong. (5) Giving a summary or affirmation of the material as well as positive reinforcement and negative reinforcement, aiming that all group members evaluate/reflect on the material that has been learned is it difficult or easy and right or wrong.

\section{Results of Model Validation / Strategy and Research Instruments}

\section{A. Results of validation of metacognition strategies based on behavioural learning}

The model/strategy validation process is one of the stages of model development, namely the third stage is develops and disseminate stage, needed to obtain a valid learning model/strategy in content or content based on three aspects, namely: aspects of guidance, aspects of coverage of elements model, and aspects of language. This model was validated by 3 experts from Halu Oleo University, consisting of 2 metacognition experts and one differential calculus expert (lecturer in calculus subjects). The results of model/strategy validation from the three validator's experts can be seen in Table 2 .

Table 2

Validation Results of Metacognition Model/Strategy based on Behavioral Learning

\begin{tabular}{|c|c|c|}
\hline Validator & Comments and Suggestions & Conclusion \\
\hline $\begin{array}{l}\text { 1. Expert in } \\
\text { Metacognition } 1\end{array}$ & $\begin{array}{l}\text { Directions: according to the theory of } \\
\text { metacognition } \\
\text { - Coverage: can reveal metacognitive } \\
\text { - } \quad \text { Lawareness } \\
\text { Language: easy to read and understand }\end{array}$ & $\begin{array}{l}\text { Behavioral based } \\
\text { metacognition } \\
\text { strategies are } \\
\text { appropriate }\end{array}$ \\
\hline $\begin{array}{l}\text { 2. Expert in } \\
\text { Metacognition } 2\end{array}$ & 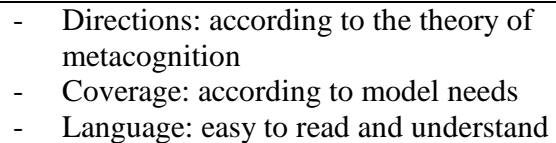 & $\begin{array}{l}\text { Behavioral based } \\
\text { metacognition } \\
\text { strategies are } \\
\text { appropriate }\end{array}$ \\
\hline $\begin{array}{l}\text { 3.Expert in calculus } \\
\text { (Calculus } \\
\text { lecturer) }\end{array}$ & $\begin{array}{ll}\text { - } & \text { Directions: relevant to calculus } \\
& \text { material } \\
\text { - } & \text { Coverage: according to model needs } \\
\text { - } & \text { Language: easy to read and understand }\end{array}$ & $\begin{array}{l}\text { Behavioral based } \\
\text { metacognition } \\
\text { strategies are } \\
\text { appropriate }\end{array}$ \\
\hline
\end{tabular}

Based on the results of the validation in Table 2, it can be concluded that the content of the model/metacognitive strategy is valid material, construction, and language, and is feasible to use. This is in accordance with the results of the study of La Misu (2014) that 
behavior learning models can increase student awareness of solving mathematical problems.

\section{B. Results of supporting instrument validation}

Supporting instruments consist of tests of metacognition awareness and mathematical abilities, interview guidelines, and teaching materials for calculus differential courses. The validation process of supporting instruments is needed to obtain a valid learning instrument and support a predetermined model/strategy. This validation is done in content or content based on three aspects, namely: material, construction, and language. This instrument was also validated by three experts from Halu Oleo University, consisting of 2 metacognition experts and one differential calculus expert (lecturer in calculus courses). The results of instrument validation from the three validated experts can be seen in Table 3 .

Table 3

Results of Validation of Research Supporting Instruments

\begin{tabular}{|c|c|c|}
\hline Validate & Comments and Suggestions & Conclusion \\
\hline $\begin{array}{l}\text { 1. Expert in } \\
\text { Metacognition } 1\end{array}$ & $\begin{array}{l}\text { - Material: according to the level of } \\
\text { awareness and ability of students } \\
\text { - Construction: can reveal } \\
\text { metacognition awareness and } \\
\text { mathematical abilities } \\
\text { - } \quad \text { Language: easy to read and understand }\end{array}$ & $\begin{array}{l}\text { Instrument worthy } \\
\text { of use }\end{array}$ \\
\hline $\begin{array}{l}\text { 2. Expert in } \\
\text { Metacognition } 2\end{array}$ & $\begin{array}{l}\text { Material: according to the level of } \\
\text { awareness and ability of students } \\
\text { - Construction: can reveal } \\
\text { metacognition awareness and } \\
\text { mathematical abilities } \\
\text { - } \quad \text { Language: easy to read and understand }\end{array}$ & $\begin{array}{l}\text { Instrument worthy } \\
\text { of use }\end{array}$ \\
\hline $\begin{array}{l}\text { 3. Expert in calculus } \\
\text { (Calculus lecturer) }\end{array}$ & $\begin{array}{ll}\text { - } & \text { Material: relevant to calculus material } \\
\text { - } & \text { Construction: can reveal } \\
\text { metacognition awareness and } \\
\text { mathematical abilities } \\
\text { - } \quad \text { Language: easy to read and understand }\end{array}$ & $\begin{array}{l}\text { Instrument worthy } \\
\text { of use }\end{array}$ \\
\hline
\end{tabular}

Based on the results of the validation in Table 3, it can be concluded that content supporting instruments are valid and feasible to use.

\section{Results of Implementation of Metacognition Strategies Based on Behaviour Learning}

\section{A. Early ability of metacognition awareness and student mathematics education mathematics}

The initial ability of metacognitive and mathematical awareness of students in mathematics education can be divided into three categories, namely initial abilities based on (1) understanding questions, (2) application questions, and (3) analysis questions. Of these three categories lead to 2 types of thinking skills, namely the ability to think of Low Order Thinking Skills (LOTS) and Hight Order Thinking Skills 
(HOTS). The initial ability of metacognition awareness and mathematical abilities of mathematics education students can be seen in Table 4 .

Table 4

The Initial Ability of Metacognition Awareness and Mathematical Abilities of Students of Mathematics Education

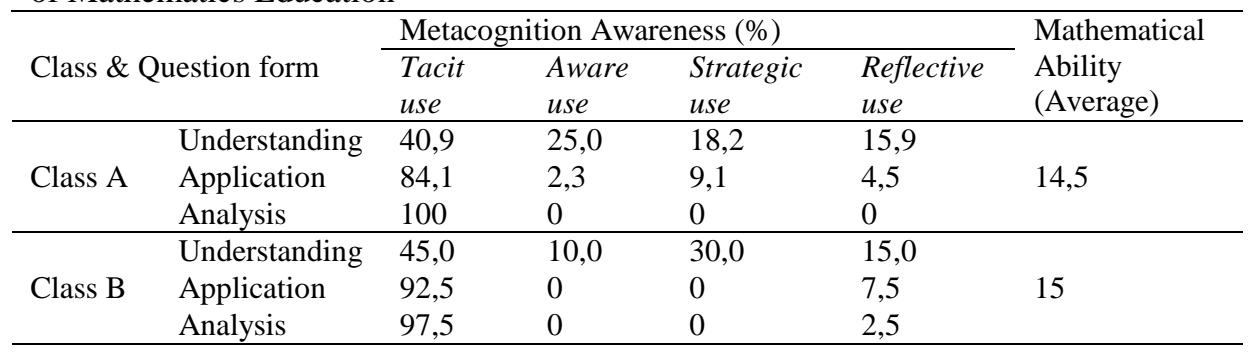

Based on Table 4, it can be seen that in class A, the initial ability of metacognitive awareness in mathematics education students is: (1) for understanding, $40.9 \%$ is at tacit use level, $25.0 \%$ is in aware use level, $18.2 \%$ is in strategic level use, and $15.9 \%$ are in the reflective use level. (2) For the application problem, $84.1 \%$ is at the tacit use level, $2.3 \%$ is in the aware use level, $9.1 \%$ is in the strategic use level, and $4.5 \%$ is in the reflective use level. (3) For the problem analysis, 100\% is still at the level of tacit use. Whereas in class $\mathrm{B}$, the initial ability of metacognitive awareness of mathematics education students: (1) for understanding, $45.0 \%$ is at the level of tacit use, $10.0 \%$ is at aware use level, $30.0 \%$ is in strategic use level, and $15,0 \%$ is in the reflective use level. (2) For the matter of application, $92.0 \%$ is at the level of tacit use, and $7.5 \%$ is at the level of reflective use. (3) For the matter of analysis, 97.5\% is at the level of tacit use, and $2.5 \%$ is level reflective use. Then, the average initial mathematical ability of class $\mathrm{A}$ mathematics education students is 14.5 , and class B is 15 .

\section{B. Metacognition and mathematical awareness of students in mathematics education in the learning process with metacognition strategies based on behavioural learning}

In the learning process, the form of the question used is a matter of application. Metacognition awareness and mathematical abilities of mathematics education students during the learning process using behavioral-based metacognition strategies can be seen in Table 5.

Table 5

Metacognition Awareness and Mathematical Abilities of Students in Mathematics Education during the Learning Process

\begin{tabular}{llllll}
\hline \multirow{2}{*}{ Class } & \multicolumn{2}{l}{ Metacognition Awareness (\%) } & Mathematical \\
\cline { 2 - 5 } & Tacit & Aware use & $\begin{array}{l}\text { Strategic } \\
\text { use }\end{array}$ & $\begin{array}{l}\text { Reflective } \\
\text { use }\end{array}$ & $\begin{array}{l}\text { Ability (Average) } \\
\text { Class A }\end{array}$ \\
\hline Class B & 27,8 & 22,7 & 27,3 & 18,2 & 44,8 \\
\hline
\end{tabular}


Based on Table 5, it can be seen that in class A, metacognitive awareness of mathematics education students: $31.8 \%$ is at the level of tacit use, $22.7 \%$ is in the level of aware use, $27.3 \%$ is in the level of strategic use, and $18.2 \%$ is level reflective use. Whereas in class B, metacognitive awareness of mathematics education students: $27.8 \%$ is at the level of Tacit use, $33.3 \%$ is in the level of aware use, $22.2 \%$ is in the level of strategic use, and $16.7 \%$ is in the level of reflective use. Then, the average mathematical ability of class A mathematics education students is 44.8 , and class B is 43.1 .

\section{Metacognition and mathematical awareness of students in mathematics education after the end of learning with a metacognition strategy based on behavioural learning}

At the end of learning with a metacognition strategy based on behavioural learning, the form of the question used is a matter of application. Metacognition awareness and mathematical abilities of students of mathematics education after the end of learning can be seen in Table 6 .

Table 6

Metacognition Awareness and Mathematical Abilities of Students of Mathematics Education after the End of Learning

\begin{tabular}{llllll}
\hline \multirow{2}{*}{ Class } & \multicolumn{2}{l}{ Metacognition Awareness (\%) } & & $\begin{array}{l}\text { Mathematical } \\
\text { Ability } \\
\text { (Average) }\end{array}$ \\
\cline { 2 - 5 } & Tacit & Aware use & Strategic & Reflective use \\
Use & & 25,7 & 17,1 & 31,5 & 53,4 \\
Class A & 25,7 & 18,2 & 24,2 & 42,4 & 66,8 \\
\hline
\end{tabular}

Based on Table 6 , it can be seen that in class A, metacognitive awareness of mathematics education students: $25.7 \%$ is at the level of tacit use, $25.7 \%$ is in the level of aware use, $17.1 \%$ is in the level of Strategic use, and $31.5 \%$ is level reflective use. Whereas in class B, metacognitive awareness of mathematics education students: $15.2 \%$ is at the level of tacit use, $18.2 \%$ is at the level of aware use, $24.2 \%$ is in the level of strategic use, and $42.4 \%$ is in the level of reflective use. Then, the average mathematical ability of students in class A mathematics education is 53.4, and class B has 66.8.

The results of the research above, it can be seen that metacognition strategies based on behavioural learning can facilitate students in understanding mathematical concepts and increasing metacognitive awareness and mathematical abilities of students of mathematics education. This can be seen in the second phase of this metacognition strategy that the two group members discuss and share knowledge in understanding mathematical concepts on a particular topic. There arises an awareness of students' metacognitive knowledge in processing information, so that information can be corrected according to the actual concept. Furthermore, it is deepened in the third and fourth phases because all group members respond to the information. Finally in the fifth phase, the lecturer provides a summary and affirmation of the information from the concept. The results of this study are in line with the research results of Rahim and La Misu (2015) that learning integral calculus through a metacognition approach makes it 
easier for students to explain and comment on each step of solving problems in integral calculus material.

While the metacognition awareness of mathematics education students at the beginning was very low, especially in the application and analysis questions, which were still 88.3\% (application questions) and 98.75\% (analysis questions) were still level 1 (tacit use). This is in accordance with the results of the study of Salam and Misu (2018) that generally the level of metacognitive awareness of Mathematics Education Department students in learning number theory through behavioural learning theory is still low, namely $57.14 \%$ at level 1 (tacit use) and only 5.36\% is on level 4 (Reflective use). Furthermore, after being given a behavioural-based metacognition strategy, the results of metacognition awareness and mathematical abilities of students of mathematics education can increase especially in the matter of analysis, ie from $0 \%$ at level 3 and $1.25 \%$ at level 4 it increases to $20.65 \%$ at level 3 and $36.95 \%$ at level 4 . The average math ability also increased from 14.75 to 60.1 .

\section{CONCLUSION}

Based on the results of the above research, it can be concluded that the form of behaviour-based metacognition strategy consists of 5 phases, namely: (1) The selection of learning approaches using the TPS-type cooperative approach, aimed at making group members more familiar and not reluctant with group members in discussions, (2) Studying lecture material by discussing it with their partners, so that each group member listens to each other or voices ideas/results of his thoughts (metacognitive knowledge) and equates perceptions about the subject matter he is studying, (3) Presents lecture material by designated group members in turn in front of the class, the goal is that all members of the group be brave and able to voice their ideas / results of thoughts (metacognitive knowledge) about the lecture material learned in front of the class, (4) The responses of other group members to material presentations from the presenter group conscious presenter $t$ the knowledge that has been possessed whether it is right or still wrong, and (5) Giving a summary or affirmation of the material as well as positive reinforcement and negative reinforcement, aiming that all group members evaluate / reflect on the material that has been studied is difficult or easy, and correct or correct wrong.

The results of metacognition awareness of mathematics education through behaviouralbased metacognition strategies can increase, especially in the matter of analysis, namely from $0 \%$ at level 3 and $1.25 \%$ at level 4 increasing to $20.65 \%$ at level 3 and $36.95 \%$ at level 4. And the results of students' mathematical abilities through behavioural-based metacognition strategies also increased, from an average of 14.75 to an average of 60.1.

\section{ACKNOWLEDGMENT}

The author would like to thank the Chancellor of the Halu Oleo University for providing research fund allocation through the Public Service Agency (BLU), so that this research can be realized. Then, thanks to the Chairperson of the Halu Oleo University Research Institute, for passing this research to obtain research funding from Halu Oleo University. Acknowledgments to the Chair of the Halu Oleo University Mathematics Education 
Department, for giving us permission to conduct research on the students they lead. The author also thanked the mathematics education students at Halu Oleo University for giving a positive response to our research instrument questions so that the results of this study can be realized.

\section{REFERENCES}

Biryukov, P. (2003). Metacognitive aspects of solving combinatory problem Kaye College of Education. Direct access: http://www. cimt. org. uk/journal-/Biryukov. pdf.

Bloom, B. S., Madaus, G. F. \& Hasting, J. T. (1981). Methods grading in summative evaluation. New York: McGraw-Hill.

Fisher, R. (1998). Thinking about thinking: Developing metacognition in children. Early Child Development and Care, 141(1), 1-15.

Flavell, J. H. (1979). Metacognition and cognitive monitoring: A new area of cognitivedevelopmental inquiry. American Psychologist, 34(10), 906-911.

Fogarty, R. (1994). The mindful school: How to teach for metacognitive reflection. Australia: Hawker Brownlow Education.

Goh, C. (2008). Metacognitive instruction for second language listening development: Theory, practice and research implications. RELC journal, 39(2), 188-213.

Gray, P. (2011). Psychology. New York: Worth Publishers.

Hacker, D. J. (1998). Definitions and empirical foundations. In D. J. Hacker, J. Dunloky, \& A. C. Graesser (Eds.), Metacognition in educational theory and practice (pp. 1-23). Mahwah, NJ: Lawrence Erlbaum Associates.

Iwai, Y. (2011). The effects of metacognitive reading strategies: Pedagogical implications for EFL/ESL teachers. The Reading Matrix 11(2), 150, 159.

Janssen, J., Erkens, G., Kirschner, P. A., \& Kanselaar, G. (2009). Influence of group member familiarity on online collaborative learning. Computers in Human Behaviour, 25(1), 161-170.

Kraler, C. (1995). Strategic teaching and reading project guidebook: Metacognition. Australia: North Central Regional Educational Laboratory

La Misu, M. P. (2014). Mathematical problem solving of student by approach behavior learning theory. This paper has been presented at International Seminar on Innovation in Mathematics and Mathematics Education, Yogyakarta, Indonesia.

Nieveen, N., \& Gustafson, K. (1999). Characteristics of computer-based tools for education and training development: An introduction. In van den Akker, J., Branch, R. M., Gusatfson, K., Nieveen, N., \& Plomp, T. (Eds.), Design approaches and tools in education and training (pp. 155-174). Dordrecht: Springer. 
Rahim, U., \& La Misu, M. P. (2015). The resolution integral approach to metacognition in math education student of Halu Oleo University. International Journal of Education and Research, 2(8) 151-158.

Salam, M., \& Misu, L. (2018, June). Searching of Student's Metacognition Consciousness in Learning of Numbers Theory through Behavioral Learning Model. Journal of Physics: Conference Series, 1028(1), 012171.

Scanlon, D. O., Watson, G. W., Payne, D. J., Atkinson, G. R., Egdell, R. G., \& Law, D. S. L. (2010). Theoretical and experimental study of the electronic structures of MOO3 and MOO2. The Journal of Physical Chemistry C, 114(10), 4636-4645.

Slavin, E. R. (2011). Educational psychology: Theory and practice. New York: Prentice Hall.

Swartz, R. J., \& Perkins, D. N. (1989). Teaching thinking: Issues and approaches. Revised edition. The practitioners' guide to teaching thinking series. Pacific Grove, CA: Midwest.

Tacccasu, Project (2008). Metacognition, (Online). Retreived from http://www.careers.hku.hk/taccasu/ ref / metacogn.htm.

Thiagarajan, S., Semmel, D. S., \& Semmel, M. I. (1974). Instructional development for training teachers of exceptional children: A sourcebook. Bloomington, Indiana: Indiana University. 